\title{
14 Monitoring implementation of the sexual and reproductive health and rights of adolescents children
}

\author{
The role of the African Committee of Experts \\ on the rights and welfare of the child
}

\author{
Ayalew Getachew Assefa
}

\section{Introduction}

The International Conference on Population and Development (ICPD) and the subsequent platform in $1995,{ }^{1}$ Platform for Action of the Fourth World Conference on Women (FWCW), ${ }^{2}$ pave the way to galvanize policy and program commitments to better address the Sexual and Reproductive Health and Rights (SRHR) of women in general and adolescent girls, in particular. Though the political commitment was concretely conceived during these two conferences, SRHR of adolescents and States' obligations towards their full realization were already embodied in prior international and regional human rights instruments, including the African Charter on the Rights and Welfare of the Child (the African Children's Charter/the Charter). Focusing on the African regional mechanism created through the African Children's Charter, the current chapter examines the role that the African Committee of Experts on the Rights and Welfare of the Child (ACERWC/the Committee) could play in monitoring implementation the SRHR of adolescents by State Parties of the Charter. In doing so, the chapter attempts to provide a critical reflection on the mandate of the ACERWC and the extent to which the Committee is engaged in addressing matters of SRHR while discharging its monitoring mandate.

Drawing from the 1998 joint statement by the World Health Organization, the United Nations Children's Fund, and the United Nations Population Fund, the chapter defines the term 'adolescents' as group of people between the ages of 10 and 19. With regard to the term 'child', the article recognizes the definition adopted by the African Children's Charter- 'any person under the age of 18'. From these definitions, one may learn that not all adolescents are treated as children, the former clearly extends to include those between the ages of 18 and 19, hence monitoring protection and promotion of their rights may not fall within the mandate of the ACERWC. Therefore, from the onset it should be noted that the scope of the chapter is limited to deal with issues

DOI: 10.4324/9781003175049-14 
of SRHR of adolescents, i.e., those between the ages of 10 and 18. However, in certain instances, the chapter may also include all children, where the rights and protections apply to all, and not only adolescents.

\section{Sexual and reproductive health and rights of adolescent children: setting the context}

Constituting a significant number globally, adolescents, like many other groups, have specific concerns, which include challenges in relation their SRHR. Though adolescents are 'relatively better educated, healthier, more aware of their rights and better equipped to advocate on their own behalf than the previous generations, many still face threats to their SRHR'. ${ }^{3}$ Reports confirm that adolescents, particularly in African countries, are generally uninformed or misinformed about their sexuality and reproductive health promoting behaviors. ${ }^{4}$ Lack of an in-depth knowledge about modern contraceptives, safe sex and safe abortion, limited access to adolescent friendly Sexual and Reproductive Health (SRH) services is reported as the major challenge of SRHR of adolescents in Africa. ${ }^{5}$ As International Planned Parenthood Federation (IPPF) states, adolescents are 'sexual beings with diverse needs, desires, hopes, dreams, problems, concerns, preferences and priorities, most of which are still unmet'. ${ }^{6}$ These unmet needs of adolescents are consequently producing various threats to their rights and welfare, such as child marriage, Female Genital Mutilation (FGM) and various forms of sexual abuse. Due to lack of access to a full range of appropriate and freely chosen contraceptives, adolescent girls experience unwanted pregnancies and sexually transmitted infections (STIs). The challenges are often exacerbated among adolescents who are in vulnerable situation, including children residing in rural areas, children with disabilities, children on the move, and belonging to economically disadvantaged households or socially excluded ethnic groups.

Despite the existing challenges, due to controversies related to adolescent sexuality and the general lack of knowledge about the SRH needs of adolescents, very few countries in Africa have adequately responded and set up the required normative and institutional standards. In fact, most countries have introduced restrictive laws and policies which fail to recognize adolescent children's capacity to make decisions about their sexual and reproductive lives and health. Many still find it sensitive and controversial to relate the discourse of children's rights with SRHR. In some cases, what comes to one's mind when she/he thinks of a 'child', may not allow the person to relate SRHR with the interest of children. Such perspectives, this chapter argues, emanate from the very understanding that society has about children, which usually attaches an unqualified reservation on children's capacity to make informed decisions. Hence, before proceeding to the main part of this article, it would be necessary to provide conceptual clarification on children's rights and how they relate to matters of SRHR. 
With regard to addressing the challenges of SRH of adolescents, it can be noted that a consensus has been reached to apply the hybrid model; this can be inferred from the agreement reached during international conferences, such as the ICPD and FWCW. According to the ICPD and FWCW framework documents, the human rights of women and girls include their right to have control over and decide freely and responsibly on matters related to their sexuality, including sexual and reproductive health, free of coercion, discrimination and violence. In relation to adolescents, the ICPD provides that 'full attention should be given to meeting the educational and service needs of adolescents to enable them to deal in a positive and responsible way with their sexuality'. Particularly, Chapter VII of the Program of Action of the ICPD states that countries should strive to address 'adolescent sexual and reproductive health issues, including unwanted pregnancy, unsafe abortion, and STDs and HIV/ AIDS, through the promotion of responsible and healthy reproductive and sexual behaviour, including voluntary abstinence, and the provision of appropriate services and counselling specifically suitable for that age group'. The document also prescribes that countries must ensure that programs and attitudes of health-care providers do not restrict adolescents' access to the services and information they need. However, recognizing the inevitable challenges that children in this age group could face and the role parents should play in the upbringing of their children, the Program of Action also requires countries, in their attempt to comply with these standards, must safeguard the right of adolescents to privacy, confidentiality, respect and informed consent, while respecting cultural values and religious beliefs as well as the rights, duties and responsibilities of parents.

Looking at these aspirations and call for actions, it is very clear that the principles of autonomy, participation, equality and non-discrimination form the basis of the terms of the consensus reached by the participating States. However, it should also be noted that the framework documents also recognize the respect of cultural values and the roles and responsibilities of parents. This entails that the framework documents advocate for 'a hybrid model' by recognizing both principles of the 'child's autonomy' and 'protection' as explained in the child liberation and child protection approaches respectively.

\subsection{Autonomy of adolescent children vis-à-vis parental authority}

The discourse around why children must be protected and the extent to which parental, or legal guardians, authority exercised over children has been explained in the three major child rights theories; namely the John Eekelaar's interest theory, the fiduciary theory, and the theory of paternalism. ${ }^{8}$ Getting into the details of these theories is not within the scope of this chapter, however; a brief mention on the 'interest theory' would be important as it helps to clearly set the context of the discussions in the forthcoming section of this article.

Drawing inspiration from Joseph Raz's theory of rights, ${ }^{9}$ John Eekelaar's interest theory asserts that children have three distinct interests which are 
separable from the interests of their parents: basic, development and autonomy interests. ${ }^{10}$ Autonomy interests relate to the freedom of the child to choose his or her own lifestyle and to enter social relations according to his or her own inclinations uncontrolled by the authority of the adult world, parents or institutions. ${ }^{11}$ Of course, the theory argues that autonomy of the child should be respected by taking into consideration the intellectual understanding, which should also be supplemented by emotional maturity, of the concerned child; ${ }^{12}$ a notion which is in line with the concept of 'the evolving capacities of the child' as recognized by international instruments.

In line with Eekelaar's interest theory, this chapter argues that recognizing the role of parents should not impede the rights of adolescent children, subject to their evolving capacities, to make autonomous decisions about their sexual and reproductive health. Practically, however, the application of this principle could rather be challenging due to the widely-held and historically rooted belief that adolescents are incapable of making positive decisions about their own sexual and reproductive health. ${ }^{13}$ This notion of rather unregulated parental autonomy led many jurisdictions in the world to hold the position that until a minor attains majority, only parents or legal guardians could provide consent for access to SRH services. ${ }^{14}$

With a view to addressing this tension between parental authority and the child's autonomy, countries tend to use different laws and policies allowing or preventing adolescents' access to SRH Services. The laws and policies may cover various instances where minimum age could be required to get access for various services, such as: legislation for age of medical decision-making like HIV counseling, testing, and treatment without parental consent (and whether the adolescent's status would be reported to her/his parents), contraceptives (with and without parental consent); emergency contraceptives (with and without parental consent); safe abortions and post-abortion care (with and without parental consent); antenatal Care (with and without parental consent); and sexual intercourse (including the age for statutory rape).

The minimum age may vary depending on the nature or seriousness of the treatment. With regard to the age for sexual consent, though majority of the countries in Africa do not have any clear standards in their legislations, there are some with laws and policies regulating age of consent to sex. Countries like Kenya, Uganda, Tanzania, Burundi, Ivory Coast and Equatorial Guinea, have set the age of consent to sex at 18 , below which any sexual activity is subject to criminal sanctions. There are also some countries with a lower age of consent such as: Comoros (13), Zambia (14), Algeria (15), Botswana (16), Angola (15), and Mozambique (16). Other countries set a higher age like the case in Namibia (19) and Burundi (20)..$^{15}$

Such age-based laws tend to either preclude consent by adolescents below the set age, by requiring parental or guardian consent, or require that they demonstrate maturity to overcome their presumed incompetency. Minimum age laws are often defended on the ground that 'age is an efficient proxy for competency....an easily measured, inescapable attribute and a quality that 
everyone has experienced or will experience'. ${ }^{16}$ The age-based rule has its own advantage as it allows adolescents over the prescribed age to presumed competent and be treated the same as adults in providing informed consent to matters related to their SRH needs. As IPPF states, 'this avoids the serious problems that arise in discretionary systems where service providers are unwilling to recognize minors' competency, particularly in SRH decisionmaking' ${ }^{17}$ Recognizing the advantage of the age-based rule, the Committee on the Convention on the Rights of the Child (the CRC Committee) has also encouraged States Parties to give consideration to the introduction of such approaches in their laws.

On the other hand, the age-based approach may preclude adolescents under the prescribed age from being recognized as capable to decide. In setting minimum ages, States should then undertake a balancing act between the need to protect and the desire to empower, and ensure that setting minimum age should aim at promoting rights and not to impede them. It should recognize 'the right of any child below that minimum age and who is able to demonstrate sufficient understanding to be entitled to give or refuse consent'.

The principle of evolving capacity of the adolescent child, therefore, plays a pivotal role in reconciling the competing interests of parental authority and autonomy of the child. Hence, it should be noted that parental decision and authority on issues of SRH of adolescents can be valid so long as it is consistent with the requirement of the evolving capacities of the child. Furthermore, age limits and parental consent should not be applied to all services in relation to SRH services as there are rights that adolescents are entitled to claim without the consent of a parent or guardian, irrespective of age.

\section{International and African regional instruments and initiatives on SRHR of adolescents}

The principles included in the Program of Actions agreed to at the ICPD and FWCW are recognized in various international and African regional human rights instruments. The rights and protections include: the right of everyone to the enjoyment of the highest attainable standard of physical and mental health, the right to life, the right to privacy, the right to reproductive self-determination, the right to consent to marriage, the right to be free from discrimination, the right to not be subjected to torture or other cruel, inhuman, or degrading treatment or punishment, the right to be free from sexual violence, the right to be free from practices that harm women and girls, and the right to education and information. The application of these general provisions is meant to benefit all persons, hence adolescents are able to enjoy the protections accorded through these instruments as adults.

In addition to these general instruments, specific protections are also provided as they apply to matters of SRHR of adolescents. For instance, the Convention on the Rights of the Child (CRC) states that every child has an inherent right to life and that the States Parties must ensure to the maximum 
extent the child's survival and development. ${ }^{18}$ States Parties shall also recognize the right of the child to the enjoyment of the highest standard of health ${ }^{19}$ and develop family planning education and services. ${ }^{20}$ Similarly, at the African level, the African Union (AU) has also adopted various regional instruments which could be relevant to matters of SRHR of adolescents. As discussed in the following sections, the African Children's Charter is one of the key regional human rights documents that contain numerous provisions which could be applicable to matters of SRHR of adolescent children.

In addition to the above-mentioned instruments, there are various documents and initiatives, both at the global and regional level, which provide guidance, primarily for states, on the nature and application of SRHR as they relate to adolescents. At the global level, the CRC Committee has developed General Comments on adolescent health and development in the context of the Convention on the Rights of the Child, and on the Implementation of the Rights of the Child during Adolescence. The 2014 Joint General Comment by the Committee on the Elimination of Discrimination against Women and the CRC Committee on the Rights of the Child on harmful practices also provides relevant standards concerning the notable link between SRHR and harmful traditional practices in line with the rights of adolescent children.

In a similar vein, the African continental bodies such as the African Union Commission (AUC), and the Human Rights Organs have developed policy documents and frameworks on SRHR and adolescent children. These include, the joint General Comment developed by the African Commission on Human and Peoples' Rights' (ACHPR) and the ACERWC on child marriage, ${ }^{21}$ the General Comments by the ACHPR on women's human rights and HIV as prescribed under Article 14 (1) (d) and (e) of the Protocol to the African Charter on Human and Peoples' Rights on the Rights of Women in Africa; 22 the AU's Continental Policy Framework for Sexual and Reproductive Health and Rights (2005), and the Maputo plan of action 2016-2030 for the operationalization of the continental policy framework for sexual and reproductive health and rights. ${ }^{23}$

\subsection{The African Children's Charter}

Adopted in 1990 and came in to force in 1999, as of October 2020, the African Children's Charter is ratified by 49 African Countries. ${ }^{24}$ Though the adoption of this Charter was influenced by its predecessor child rights instruments, such as, the CRC, the 1924 and the 1959 Declarations, it has revealed itself with some form of peculiarities to advance the protection of children in Africa. ${ }^{25}$ Relevant to the theme of this chapter, the African Children's Charter includes provisions that can apply to protect the SRHR of adolescents. For instance, the African Children's Charter states that 'State Parties shall take specific, legislative, administrative, social and educational measures to protect the child from all forms of torture, inhuman and degrading treatment especially physical or mental injury or abuse, neglect or maltreatment, including sexual abuse, while in the care of 
the child'. The elements of this provision should be understood as they cover various aspects. Applying the protection under similar provisions in international and regional laws to matters of SRHR, human rights bodies have found that the denial of sexual and reproductive health services to adolescents can amount to cruel, inhuman and degrading treatment. Other protections are also available in the right to education, parental responsibilities, protection against harmful social and traditional practices, the right to health and health services.

The provisions under article 14 have particular relevance. Article 14 (1) of the Charter guarantees every child's right to 'enjoy the best attainable state of physical, mental and spiritual health', while article 14 (2) enumerates illustrative, non-exhaustive list of States Parties' obligations. The illustrations under article 14 (2) covers States' obligations to reduce child mortality, access to health care services to all children, ensuring adequate nutrition, drinking safe water, health education and establishment of health care mechanisms, and resource mobilization for implementation of health care services. Hence, in defining the right to health and health services under article 14 (1), one should consider the elements presented under article 14(2) of the Charter, which then enables States to take a broader approach and include SRH and services in implementing their obligations. In line with this approach of adopting a purposive interpretation of the right to health and health services, the CESCR Committee states 'the right to health as an inclusive right extending not only to timely and appropriate health care but also to the underlying determinants of health, such as access to safe and potable water and adequate sanitation, an adequate supply of safe food, nutrition and housing, healthy occupational and environmental conditions, and access to health-related education and information, including on sexual and reproductive health'. ${ }^{26}$ This entails, .implementation of the obligations under article 14 of the African Children's Charter ensures the existence of accessible health care services to all, which also respond to the SRH needs of adolescent children. Moreover, it should also be noted that States obligations under the right to health goes beyond provision of goods and services, and include ensuring 'both freedoms and entitlements, including the right to control one's health and body, including sexual and reproductive freedom, and the right to be free from interference'.

Drawing inspiration from the CRC Committee, the ACERWC has also identified what it calls 'general principles' of the Charter which aim at ensuring a common philosophical approach to the spectrum of areas addressed by the Charter. The principles of non-discrimination, the best interests of the child, the right to life, survival and development, and respect for the views of the child, set the underlying and fundamental values that are relevant to the realization of all children's rights, including SRHR.

\section{The Role of the ACERWC in Monitoring the implementation of SRHR under the African Children's Charter}

The African Children's Charter establishes the ACERWC to promote and protect the rights and welfare of the child. Drawing it mandate from article 42 
of the African Children's Charter, the ACERWC monitors implementation of the Charter. Accordingly, the ACERWC may receive and consider State Party Reports on the status of implementation of the African Children's Charter, receive and consider Communications, and resort to any appropriate method of investigations to address any matter under the Charter.

\subsection{The role of the State Party reporting mechanism within the ACERWC}

In line with article 43 of the Charter, State Parties shall submit reports to the ACERWC on measures that they have taken to give effect to and implement the provisions of the Charter. The Reports serve as the basis for the Committee's evaluation of the degree to which the Charter is implemented by the respective State Parties. Hence, the Reports should contain information which enables the Committee understand the administrative, judicial and other measures that the Government has taken to implement the Charter, and indicate factors and difficulties that are affecting the fulfilment of the obligations contained in the charter.

According to the Committee's Procedure of Consideration of State Party Reports, the Committee considers State Party Reports during one of its Ordinary Sessions in the presence of representatives of the concerned county. ${ }^{27}$ Once the Committee finalizes its discussion with the State Party concerned and other stakeholders, it then prepares its concluding observations and recommendations. The concluding observations and recommendations, inter alia, highlight the progress that the State Party has achieved in implementing the provisions of the Charter, the major issues of concern, and the Committee's suggestions and recommendations on what needs to be done in a better way.

The contents of the concluding observations and recommendations are aligned with what the State Parties are expected to include in their reports in accordance with the Committee's Guidelines on Periodic State Party Reports. Accordingly, the concluding observations and recommendations focus on the following major issues: General measures of implementation; Definition of the child; General principles; Civil rights and freedoms; Economic, social and cultural rights; Family environment and alternative care; Rights and protection of vulnerable children; Harmful practices and exploitation' Administration of juvenile justice; and Responsibilities of the child.

The State Party reporting mechanism gives the Committee an ample opportunity to play a valuable role in monitoring implementation of States' obligations to realize SRHR of adolescents as protected under the African Children's Charter. The Committee's role in this regard can be introduced at various stages of the State Party reporting procedure. Looking at Committee's Guidelines, one may learn that State Parties are under obligation to provide information on SRHR of adolescents as part of the following clusters of rights and obligations: General measures of implementation; General principles; Economic, social and cultural rights; Rights and protection of children in vulnerable situation; and Harmful practices. 
The principle of non-discrimination is of particular significance in the area of SRHR of adolescents, where discrimination may be manifested through various instances in different forms. For instance, gender inequality and social norms may discriminate against and hinder fulfilment of the SRHR of adolescent girls in general and those in vulnerable situation in particular. Adolescents who belong to a particular group, such as lesbian, gay, transgender and bisexual, may also face stigma and discrimination in accessing SRH services which respond to their particular needs. Where adolescents age or gender is joined with another basis for discrimination, such as disability, race, or migration status, the discrimination they face in exercising their SRHR can be greatly exacerbated and also manifest in unique ways. Therefore, States should proactively take targeted measures to ensure that adolescents facing multiple forms of discrimination are able to exercise their sexual and reproductive rights on the basis of substantive equality. Particularly, due to the disproportionate impact this has on girls, guaranteeing all adolescents' right to make autonomous decisions about their sexual and reproductive health and rights is a critical component of the right to equality and non-discrimination. In line with this, treaty monitoring bodies, such as the CEDAW Committee, recognize that restrictive laws on sexual and reproductive health services, such as laws restricting the legality of specific services and requiring third-party authorization, violate the right to non-discrimination.

Similarly, the principle of the best interests of the child is of a particular relevance to realize the full implementation of the standards of SRHR of adolescents. For example, if the best interests of the child so require, States may justify intervention to order the medical treatment of a child even if a parent has refused consent. Similarly, in cases where the child's views and/or interests are distinct from those of parents, the best interests test can be used to legitimately respect the child's right to receive sexual and reproductive health services, including counseling and treatment, and override parental consent.

With regard to the principle of life, survival and development, as Sutherland, states 'it would be difficult to imagine anything more fundamental in the whole panoply of human rights than recognition of the right to life'. ${ }^{28}$ In line with this, the United Nations Human Rights Committee (HRC) has described 'the right to life' as 'the supreme right from which no derogation is permitted even in time of public emergency which threatens the life of the nation'. Indeed, 'the right to life', as it applies to all human beings, seems to get a universal acceptance and had already been guaranteed to all people by various international and regional instruments. In addition to the right to life, by guaranteeing the right to survival and development, article 5 goes further and recognizes State Parties' obligation to take measures to ensure the survival, protection and development of the child. The right to survival and development is defined by treaty bodies, such as the CRC Committee, in its broadest sense as 'a holistic concept, embracing the child's physical, mental, spiritual, moral, psychological and social development'. Therefore, as part of their obligation, States Parties are under obligation to ensure a full and harmonious development of the child, 
including at the spiritual, moral and social levels, where education, provision of health services, the provision of adequate information or knowledge on nutrition, hygiene and environmental sanitation play a great role.

Despite the far-reaching relevance of the right to education to matters of SRH of children, the Committee's Guidelines appears to be relatively limiting as it requires States to report only on the measures they have taken to address the challenges of girls who become pregnant while they are in schools. ${ }^{29}$ Despite the limiting approach adopted by the Guidelines, it would then be paramount for the Committee to adopt a holistic approach to the right to education and require the reporting States to furnish more information regarding the measures it has undertaken in ensuring the implementation of SRHR of children through education. As mentioned above, the Charter prescribes that education must ensure the promotion and development of physical development of the child and foster human rights and fundamental freedoms in line with international and regional instruments. The information States should provide in this regard may include the measures they have undertaken to introduce a comprehensive reproductive and sexuality education for adolescent children.

Referring to the obligations under article 14 of the African Children's Charter, the Committee's Guidelines set one of the most directly applicable obligations of States concerning implementation of SRHR of children. ${ }^{30}$ The Guidelines require, State Parties to provide relevant and updated information on the measures taken to ensure that every child enjoys the best attainable state of physical, mental and spiritual health. Particularly, States are required to report on the measures taken to reduce infant and child mortality; to ensure access to health and health services, which also includes SRH Services, to ensure appropriate health care for expectant and nursing mothers; and to prevent transmission of HIV from mother to child. Looking at the particulars that the Guidelines provide, it seems that, similar to the case of the right to education, the Committee's Reporting Guidelines chooses to follow a restrictive approach. The current article is of the view that ensuring every child's enjoyment of the best attainable state of physical, mental and spiritual health, requires a more comprehensive response, which definitely goes beyond what has been enumerated in the Committee's Reporting Guidelines.

State Parties have also the obligation to provide relevant and updated information on the nature, type and prevalence of harmful social and cultural practices within its jurisdiction. As part of their reports, States are expected to identify practices which could stem from deeply entrenched discriminatory views as they relate to SRHR. The role and position of girls in society, for instance, may legitimize and perpetuate various forms of violence against the SRHR of girls. In particular, States Parties need to provide information on the measures they have undertaken to address the adverse effects of such harmful practices on the SRHR of adolescents, such as such as child marriage, FGM, practices that prevent women from controlling their own fertility, son preference, female infanticide, early pregnancy and bride price.

From the above discussions, one may learn that the State Party reporting mechanism creates an ample opportunity for the Committee to address the 
challenges that children in Africa are facing in relation SRHR. This would, however, require the Committee to better mainstream SRHR and attempt to call upon, particularly through the concluding observations and recommendations, African States to better address the challenges of adolescents in relation to their SRHR.

Looking at the current practice within the Committee, one may learn that the ACERWC's attempt to include issues of SRHR in its concluding observations and recommendations seems to be general and limited in nature and content. As it can be gathered from most of the concluding observations and recommendations, the Committee attempts to address SRHR of adolescents, mainly, as they relate to the right to health and health services. For instance, in its concluding observations and recommendations to the Governments of Eritrea, ${ }^{31}$ Cameroon, ${ }^{32}$ Ghana, ${ }^{33}$ Tanzania,,${ }^{34}$ Chad,,${ }^{35}$ Comoros, ${ }^{36}$ Niger, ${ }^{37}$ and Sierra Leone, ${ }^{38}$ the Committee recommends to the respective State Parties to ensure provision of health services which is appropriate to children's health needs and staffed with adequate and trained health personnel. ${ }^{39}$ The Committee has also constantly urged State Parties to increase budgetary allocation to the health sector and ensure health services are easily accessible to all children in the respective country, including to those in rural areas and in vulnerable situations. ${ }^{40}$

While monitoring the implementation of article 14 on the right to health, it is only in limited cases that the Committee specifically refers to the SRHR challenges of adolescents. For instance, in its recommendations to the Government of Sierra Leone, the Committee notes that the State Party should work towards addressing the specific health needs of adolescents by providing age-appropriate information and sensitization about reproductive health and sexually transmitted diseases/infections. ${ }^{41}$ Similarly, in its recommendations to the Government of Ghana, the Committee states that the Government should provide sufficient contraception especially to children to prevent unwanted pregnancies and STIs, and ensure that Family Planning Centres exist throughout its territory and are staffed with adequate and well-trained personnel to address the sexual and reproductive needs of children. ${ }^{42}$ The Committee also addresses the challenges of HIV/AIDS by calling on State Parties to increase the number of health professionals trained on management of HIV/AIDS and the availability of ART to pregnant women and children who are living with the virus. $^{43}$

Though the Committee takes an encouraging step towards addressing issues related to SRHR of adolescents, most of the Committee's observations and recommendations are general in nature and limited only to 'basic health and services', which is not in line with the comprehensive nature of the protection under Article 14 of the Charter. This limited approach to monitoring the right to health and health services can be inferred from the fact that in most of its observations and recommendations, the Committee contentiously refer only to implementation of national health policies, disparity in equal access to health care services, lack of trained health care 
personnel and quality of service delivered in health centres, budget allocation for the health sector, and universal immunization. In addition to the protection under Article 14 of the Charter, the Committee has also used other clusters of rights to monitor State Parties obligations to implement SRHR of adolescents. The most commonly used clusters of rights in this regard relate to State Parties obligation under Article 27 of the Charter on sexual exploitation, and Article 21 on protection against harmful social and cultural practices.

\subsection{The role of the communication and investigation procedures within the ACERWC}

In line with article 44 of the ACERWC, which provides the locus standi and criteria for consideration of Communications, the ACERWC has adopted the Revised Guidelines for the Consideration of Communications. Among the Communications brought before the ACERWC, one is most relevant to matters of SRHR; i.e., Institute for Human Right and Development in Africa and Finders Group Initiative on behalf of TFA (a minor) $v$. the Republic of Cameroon, ${ }^{44} \mathrm{a}$ case particularly features rape at the center of its allegations Establishing violations of various articles of the Charter, the Committee pronounces that rape forms a gender based violence which amounts to gender based discrimination. The Committee reached at this conclusion considering the fact that rape disproportionately affects women and nullifies the enjoyment of several of their human rights. As discrimination is understood to be a differential treatment on a prohibited ground and that nullifies the enjoyment of rights. The Committee then recommends for the Government of Cameroon, among others, to enact and implement a legislation eliminating all forms of violence, including sexual violence against children; to train its police, prosecutors, and judiciary; establish a mechanism to support victims of sexual abuse, and to work towards the elimination of practices, custom, and stereotypes that legitimize abuse of children. The Decision and its recommendations, therefore, immensely contribute for implementation of SRHR of adolescents as violence against girls, such as rape, directly affects their reproductive rights and their right to sexual health.

In line with its mandate under article 45 (i) of the Charter, and the subsequent Guidelines that the Committee adopted, the ACERWC, in recent years, has conducted investigation missions to Countries such as South Sudan, Central African Republic (CAR) and Tanzania. ${ }^{45}$ Though the main focuses of the investigations are not directly related to SRHR of adolescents, the Committee in its findings and recommendations indeed attempted to point out issues, though not adequately, relevant to therein. For instance, the Committee's reports on its investigative missions to South Sudan and CAR clearly cover various forms of violations that children in the respective countries are facing, sexual violence being one of them. In assessing the impact of conflict on children in South Sudan and CAR, the Committee concluded that the extent to 
which these wars are being waged directly upon the children in the countries is apparent from the violent abduction of children, and the confirmed incidents of rape of both girls and boys. ${ }^{46}$ In South Sudan, the Committee highlighted the particular SRHR challenges of adolescent girls, especially those living in the Protection of Civilian Centers (POCs) ${ }^{47}$ Investigating the challenges of children in conflict settings, the Committee could have done more by referring to the obligations of the respective States to address maters such as increased exposure to coerced sex, early and forced marriage and childbearing, increased risk-taking associated with gender roles in family circles, and reduced availability of adolescent sexual and reproductive health services. Similarly, in its investigation mission to Tanzania, concerning the case of children with albinism, ${ }^{48}$ the Committee has overlooked to address the SRHR challenges of adolescents with albinism. Using its wider mandate in investigations, the Committee should also strengthen its role in monitoring the full implementation of SRHR of adolescents, by initiating the procedure on its own motion, suo motu.

\section{Conclusion}

Taking the diverse range of barriers that adolescents are facing in relation to their right to sexual and reproductive health services, the current article attempts to explain the role that the ACERWC could play in monitoring the implementation of SRHR of adolescent children in Africa. While encouraging steps have been taken, particularly through State Party, Communications and Investigation procedures, it is noted that the ACERWC's response to the challenges of adolescent children in matters related to SRHR happens to be rather limited. Much remains to be done especially in Africa where laws, cultural practices, social norms that stigmatize adolescents' sexuality and limit access to information on sex and sexuality for adolescent children, are adversely impacting on their development and behaviour. The ACERWC should strategically engage countries with restrictive laws and policies which prohibit adolescents from accessing sexual and reproductive health services, and provide guidance on addressing the major barriers for the realization of SRHR rights of adolescent children in Africa. Such normative barriers may include laws and policies which deny adolescents the right to access sexual and reproductive health services, laws and policies which require parental or judicial notification or authorization. The Committee should also pronounce itself on special protection measures for adolescent children; including protection against violations of adolescents' reproductive rights, such as measures to control girls' sexuality and forced or coerced medical interventions.

\section{Notes}

1 International Conference on Population and Development, available at https://www. unfpa.org/icpd\# (accessed 20 November 2020).

2 Fourth World Conference on Women, available at https://www.unfpa.org/events/ fourth-world-conference-women (accessed 18 November 2020). 
3 K Santhya \& S Jejeebhoy 'Sexual and reproductive health and rights of adolescent girls: Evidence from low- and middle-income countries' (2015) 10 Global Public Health 191.

4 As above 203.

5 Center for Reproductive Rights 'Implementing adolescent reproductive rights through the convention on the rights of the child' Briefing Paper (2010) available at https:// www.reproductiverights.org/sites/crr.civicactions.net/files/documents/pub_bp_implementingadoles.pdf (accessed 10 November 2020).

6 IPPF 'Understanding young people's right to decide' (2012) available at https://www .ippf.org/sites/default/files/ippf_right_to_decide_02.pdf (accessed 15 December 2019).

7 ICPD para 7.6

8 For more discussion on these theories See L Mkandawire 'The balance between child autonomy and parental autonomy in Malawi; an analysis of the childcare, protection and justice act' (2017) unpublished Master thesis, University of Cape Town.

9 J Raz 'Legal rights' (1984) I Oxford Journal Legal Studies 13-14.

10 J Eekelaar 'The emergence of children's rights' (1986) Oxford Journal of Legal Studies 170.

11 As above 171.

12 As above 181.

13 IPPF (n 6 above).

14 As above.

15 G Kangaude \& A Skelton '(De)criminalizing adolescent sex:A rights based assessment of age of consent laws in Eastern and Southern Africa' (2018) available at https://journals. sagepub.com/doi/full/10.1177/2158244018806036 (accessed 25 January 2019).

16 As above.

17 As above.

18 See article 6 of the Convention

19 See article 24 of the Convention and Committee on CRC General Comment 15 in this regard.

20 See for instance, Committee on CRC General Comment 3 on HIV/AIDS and General Comment 4 on Adolescent Health and Development para 28.

21 See Joint general comment of the African Commission on Human and Peoples' Rights (ACHPR) and the African Committee of Experts on the Rights and Welfare of the Child (ACERWC) on ending child marriage adopted by the African Commission on Human and Peoples' Rights (ACHPR) and the African Committee of Experts on the Rights and Welfare of the Child (ACERWC) 2017.

22 See General Comment 1 on article 14 (1) (d) and (e ) of the Maputo Protocol adopted by the African Commission in 2012, see also, General Comment 3 on other provisions of article 14 of the Maputo Protocol

23 African Union Commission, the Maputo plan of action 2016-2030 for the operationalization of the continental policy framework for sexual and reproductive health and rights, (2015) available at https://www.au.int/web/sites/default/files/newsevents/workingdocuments/27513-wd-sa16952_e_original_mpoa.pdf (accessed 22 February 2019).

24 Six Member States are yet to ratify the Charter, these Countries are: DRC, South Sudan, Sahrawi Arab Democratic Republic, Somalia, Morocco and Tunisia.

25 T Kaime The African Charter on the Rights and Welfare of the Chile: A socio-legal perspective (2009) 130.

26 The General Comment refers to UN CESCR 'The right to the highest attainable standard of health General Comment No. 14: The right to the highest attainable standard of health (Art. 12)' General Comment No. 14 UN Doc. E/C.12/2000/4 (2000 para 1.

27 Between 2002 and 2019, the Committee has held 34 Ordinary Sessions and 18 pre-sessions.

28 E Sutherland 'The child's right to life, survival and development: Evolution and progress' (2015) available at https://www.researchgate.net/profile/Elaine_Sutherland2/publication/304784603_The_Child's_Right_to_Life_Survival_and_Development_Evolution and_Progress/links/5bbced3a92851c7fde3748f2/The-Childs-Right-to-Life-Survival -and-Development-Evolution-and-Progress.pdf (accessed 30 December 2018). 
29 ACERWC 'Guidelines on the Form and Content of Periodic State Party Reports to be Submitted Pursuant to Article 43(1)(b) of the African Charter on the Rights and Welfare of the Child' available at https://acerwc.africa/ (accessed 24 November 2018).

30 As above.

31 ACERWC 'Concluding observations and recommendations to the government of Eritrea' available at https://acerwc.africa/wp-content/uploads/2018/14/Concluding \%20Observations_\%20Eritrea.pdf (accessed 15 February 2019).

32 ACERWC 'Concluding observations and recommendations to the government of Cameroon' available at https://acerwc.africa/wp-content/uploads/2018/14/Concluding \%20observations_\%20Cameroon_ACERWC-2016.pdf (accessed 15 February 2019).

33 ACERWC 'Concluding observations and recommendations to the government of Ghana' available at https://acerwc.africa/wp-content/uploads/2018/14/Concluding _oberservation\%20Ghana.pdf (accessed 15 February 2019).

34 ACERWC 'Concluding observations and ecommendations to the Government of Tanzania’ available at https://acerwc.africa/wp-content/uploads/2018/14/CO_ Tanzania_eng.pdf (accessed 15 February 2019).

35 ACERWC 'Concluding Observations and Recommendations to the Government of Chad' available at https://acerwc.africa/wp-content/uploads/2018/14/Concluding \%20Observations\%20Chad\%20Fr.pdf (accessed 15 February 2019).

36 ACERWC 'Concluding Observations and Recommendations to the Government of Comoros' available at https://acerwc.africa/wp-content/uploads/2018/14/Concluding \%20Observations\%20Comoros\%20Fr.pdf (accessed 15 February 2019).

37 ACERWC 'Concluding Observations and Recommendations to the Government of Niger' available at https://acerwc.africa/wp-content/uploads/2018/14/CO_Niger _French.pdf (accessed 15 February 2019).

38 ACERWC 'Concluding Observations and Recommendations to the Government of Sierra Leone' available at https://acerwc.africa/wp (accesed 15 March 2019)-content/ uploads/2018/14/Sierra\%20Leone_Concludig\%20Observation\%20final_English.pdf (accessed 15 February 2019).

39 ACERWC 'Concluding Observations and Recommendations' available at https:// acerwc.africa/reporting-table/ (accessed 1 December 2019).

40 As above.

41 ACERWC 'Concluding Observations and Recommendations to the Government of Sierra Leone' (n. 38)

42 ACERWC 'Concluding Observations and Recommendations to the Government of Ghana' (n. 33).

43 ACERWC 'Concluding Observations and Recommendations, available at https:// acerwc.africa/reporting-table/ (accessed on 01 December 2019)

44 ACERWC 'Communication No 006/Com/002/2015' IHRDA and Finders Group Initiative v Cameroon (2015) available at https://acerwc.africa/wp-content/uploads/2018/ 13/Cameron\%20Rape\%20Case.pdf.

45 ACERWC 'Missions and country visits by the ACERWC' (2014) available at https:// www.acerwc.africa/missions-country-visits/ (accessed 15 January 2019).

46 ACERWC 'Missions reports' available at https://acerwc.africa/missions-country-visits/ (accessed 15 January 2019).

47 ACERWC 'Report on the advocacy mission to assess the situation of children in South Sudan' (2018) available at https://acerwc.africa/wp-content/uploads/2018/11/ Advocacy_Mission_South_Sudan_English_PAGES-ilovepdf-compressed.pdf (accessed 15 January 2019).

48 ACERWC 'Report on investigation mission on the situation of children with albinism in temporary holding shelters in Tanzania' (2016) available at https://acerwc.africa/ wp-content/uploads/2018/07/Investigative_Mission_on_the_Situation_of_Children_ with_Albinism_A4.pdf (accessed 15 January 2019). 


\section{References}

ACEREC 'Guidelines on the conduct of investigation by the ACERWC' https://acerwc .africa/wpcontent/uploads/2018/07/ACERWC_Guidelines_on_Investigation.pdf (accessed 15 January 2019)

ACERWC 'Guidelines on the form and content of periodic state party reports to be submitted pursuant to Article 43(1)(b) of the African charter on the rights and welfare of the child' https://acerwc.africa/ (accessed 24 November 2018)

ACERWC 'Missions and country visits by the ACERWC' https://www.acerwc.africa/ missions-country-visits/ (accessed 15 January 2019)

ACERWC 'Missions reports' https://acerwc.africa/missions-country-visits/ (accessed 15 January 2019)

ACERWC 'Report on investigation mission on the situation of children with albinism in temporary holding shelters in Tanzania' (2018), https://acerwc.africa/wp-content /uploads/2018/07/Investigative_Mission_on_the_Situation_of_Children_with_ Albinism_A4.pdf (accessed 15 January 2019)

ACERWC 'Report on the advocacy mission to assess the situation of children in South Sudan' (2018) https://acerwc.africa/wpcontent/uploads/2018/11/Advocacy_Mission _South_Sudan_English_PAGES-ilovepdf-compressed.pdf (accessed 15 January 2019)

Adolescent Pregnancy https://www.who.int/news-room/fact-sheets/detail/adolescent -pregnancy (accessed 20 November 2018)

African Union Commission, Continental Policy Framework for Sexual and Reproductive Health and Rights (2005) https://au.int/sites/default/files/documents/30921-doc-srhr _english_0.pdf (accessed 22 February 2019)

Andrews, H \& Gelsomino, P 'The legal representation of children in custody and protection proceedings: a comparative view' in Abella, R \& Heureux-Dubé, C (eds) Family law: Dimensions of justice (Butterworths 1983) 240.

Archard, D Children: Rights and childhood (New York 1993)

Aries, P Centuries of childhood: A social history of family life (Librairie Plon 1960)

Breen, C Age discrimination and children's rights (Martinus Nijhof 2006)

Eekelaar, J 'The emergence of children's rights' (1986) 6 Oxford Journal of Legal Studies 161.

Farson, R Birth rights (Penguin Books 1978)

Freeman, $M$ The rights and wrongs of children (Francis Pinter 1983)

Freeman, M 'Taking children's rights more seriously' in Alston, $\mathrm{P}$ (ed) Children, rights and the law (Palgrave Macmillian 1992) 377.

Goldstein, J \& Solnit, A Goldstein, $S \&$ Freud, A the best interests of the child: The least detrimental alternative (Free Press 1996)

Holt, J Escape from childhood: The needs and rights of children (Boston 1974)

Implementing adolescent reproductive rights through the convention on the rights of the child, briefing paper by center for reproductive rights https://www.reproductiverights .org/sites/crr.civicactions.net/files/documents/pub_bp_implementingadoles.pdf (accessed 10 November 2018)

IPPF Understanding young people's right to decide https://www.ippf.org/sites/default/ files/ippf_right_to_decide_02.pdf (accessed 15 December 2018)

Kaime, T The African charter on the rights and welfare of the chile: A socio-legal perspective (PULP 2009)

Kangaude, G \& Skelton, A '(De)Criminalizing adolescent sex: A rights based assessment of age of consent laws in eastern and Southern Africa' (2018) 8 SAGE Journals 1. 
Mindzie, M 'Regional protection of child rights in Africa' in Abbas, $\mathrm{H}$ (ed) Africa's long road to rights: Reflections on the 20th anniversary of the African commission on human and peoples' rights (Falana Books 2008) 50.

Mkandawire, L 'The balance between child autonomy and parental autonomy in Malawi; an analysis of the childcare, protection and justice act' Unpublished, University of Cape Town, 2017

Raz, J 'Legal rights' (1984) 4 Oxford Journal Legal Studies 1.

Roemer, R 'Legislation on contraception and abortion for adolescents' (1985) 16 Studies in Family Planning 241.

Santhya, K \& Jejeebhoy, S 'Sexual and reproductive health and rights of adolescent girls: Evidence from low- and middle-income countries' (2015) 10 Global Public Health 191.

Shalev, C 'Rights to sexual and reproductive health: The ICPD and the convention on the elimination of all forms of discrimination against women' (2000) 4 Health and Human Rights Journal 38

Sutherland, E 'The child's right to life, survival and development: Evolution and progress' (2015) 26 Stellenbosch Law Review 272

UNFPA 'Taking SRHR to young people living with disabilities' (2018) https://malawi .unfpa.org/en/news/taking-srhr-young-people-living-disabilities (accessed 24 January 2019)

Viljoen, F 'The African charter on the rights and welfare of the child' in Boezaart, $\mathrm{T}$ (ed) Child Law in South Africa (JUTA 2009) 335. 
$\because$ Taylor \& Francis Taylor \& Francis Group http://taylorandfrancis.com 